\title{
FRESHWATER FISH AND DECAPOD CRUSTACEAN POPULATIONS ON RÉUNION ISLAND, WITH AN ASSESSMENT OF SPECIES INTRODUCTIONS.
}

\author{
P. KEITH \\ Muséum National d'Histoire Naturelle, laboratoire d'ichtyologie, 43 rue Cuvier, \\ 75231 PARIS Cedex 05, France. \\ et \\ Conseil Supérieur de la Pêche, 134 Avenue de Malakoff, 75016 PARIS, France.
}

Reçu le 04 janvier 2002

Received 04 January, 2002

Accepté le 07 mars 2002

Accepted 07 March, 2002

\begin{abstract}
Streams of Réunion Island shelter with 26 fish species and 11 decapod crustacean species. Some species have been introduced $(18 \%)$, some other are endemic to the island or to the Madagascar-Mascarenes region (16.2\%), are originated from Indo-Pacific area $(35.2 \%)$ or from Indo-African area $(27 \%)$. Gobiidae and Palaemonidae are the prevailing family in freshwaters, with the highest number of species. 16 species were introduced, mainly fishes, beginning at the turn of the $19^{\text {th }}$ century, but only 4 of those have become acclimatised, while 7 have disappeared and the status of the other is uncertain.
\end{abstract}

Key-words : fishes, decapod crustacean, freshwater, Réunion Island, Mascarenes, introduction.

\author{
LES PEUPLEMENTS DE POISSONS ET DE CRUSTACÉS \\ DÉCAPODES DES EAUX DOUCES DE L'ÎLE DE LA RÉUNION \\ ET BILAN DES INTRODUCTIONS.
}

\section{RÉSUMÉ}

L'île de la Réunion abrite 26 espèces de poissons et 11 de crustacés décapodes. Certaines espèces ont été introduites (18\%), d'autres sont endémiques de l'île ou de la région Madagascar-Mascareignes (16,2\%), la grande majorité étant distribuée dans la région Indo-Pacifique $(35,2 \%)$ ou dans la région Indo-Africaine (27\%). Les Gobiidae et les Palaemonidae constituent les familles dominantes dans les eaux douces avec le plus grand nombre d'espèces. 16 espèces ont été introduites, principalement des poissons, à partir du $19^{\text {ème }}$ siècle mais seulement 4 se sont acclimatées, 7 ont disparu et le statut des autres est incertain.

Mots-clés : poissons, crustacés décapodes, eau douce, île de la Réunion, Mascareignes, introduction. 


\section{INTRODUCTION}

Réunion Island is a French overseas department located in the Indian Ocean, east of Madagascar. Together with the islands of Mauritius and Rodrigues, it makes up the Mascarenes. With an area $2512 \mathrm{~km}^{2}$, Réunion is located in the Indian Ocean at approximately $21^{\circ} \mathrm{S}$, about $700 \mathrm{~km}$ from Madagascar and $160 \mathrm{~km}$ from Mauritius (KEITH et al., 1999).

The earliest studies on Réunion's freshwater fauna were initiated in the $19^{\text {th }}$ century when CUVIER and VALENCIENNES (1837) described several species of fish from the island. But the first comprehensive list (for the time) of marine and freshwater fish was drawn up by GUICHENOT (1862), in Maillard's book. BLEEKER and POLLEN (1874), SAUVAGE (1891), PELLEGRIN (1933), ARNOULT (1959), and KIENER (1963a, b) added to this list when working on Madagascan fish fauna by mentioning that some of these species were found in the Mascarenes, notably on Réunion.

Very few global studies were carried out on freshwater crustaceans found on Réunion and in 1862, MAILLARD regretted not being able to give the list of species present in its waters. However, various scientists working on crustaceans from Madagascar or the Indo-Pacific region also studied those species found on Réunion, thus bringing some light on its fauna. Among them COUTIĖRE (1901a, b), ROUX (1934), and HOLTHUIS $(1950,1952,1965,1980)$. In 1981, KIENER carried out the first comprehensive study on freshwater fish and crustaceans present on the island. He described the island's fauna as a « greatly depleted Madagascan fauna with very few components from Madagascan populations found on Réunion ».

These often old and non-specific studies on freshwater fish and crustaceans from Réunion needed updating and the French Ministry of the Environment (DIREN) initiated in 1990 an ambitious programme aimed at catalogueing and describing the island's freshwater habitats. The objective was to improve knowledge on the distribution, ecology, and biology of aquatic species, in particular of introduced species, and to provide the administrative authorities with adequate tools for monitoring and conserving indigenous populations. The first steps were the publication of a reference book, the "Atlas of freshwater fish and crustaceans in Réunion " (KEITH et al., 1999), the implementation of a monitoring network for freshwater populations, and the characterization of the various habitats. This work was initiated by the DIREN and conducted by the Réunion's Association for the Development of Aquaculture (ARDA), with the methodological support of the French Fisheries Council (CSP), and the scientific support from the Muséum National d'Histoire Naturelle in Paris (MNHN) and in Saint Denis de La Réunion (BOSC et al., 1997; KEITH et al., 1999).

The aim of this paper is to provide the state of knowledge about the freshwater fauna of Réunion Island with an assessment of species introduction.

\section{FRESHWATER FAUNA}

Table I and Table II list all the species of Réunion Island. They include all diadromous, vicarious, complementary and sporadic (according to MYERS, 1938) indigenous species, plus all introduced species. 26 fish species (Table I) and 11 decapod crustacean species (Table II) were found; 30 of them are indigenous while 7 were introduced.

According to MYERS (1938) and BANARESCU (1990), true freshwater species belong to two different groups: primary fish species with families restricted to freshwaters; 
and secondary fish species with families whose members can cross narrow salty sea barriers to reach a new river basin.

\section{Table I}

Fishes species of Réunion Island and distribution area.

\section{Tableau I}

Espèces de poissons de la Réunion et aire de distribution.

\begin{tabular}{|c|c|}
\hline Species & oution area (1) \\
\hline $\begin{array}{l}\text { Anguillidae } \\
\text { Anguilla bengalensis (Gray, 1831) } \\
\text { Anguilla marmorata (Quoy and Gaimard, 1824) } \\
\text { Anguilla mossambica (Peters, 1852) } \\
\text { Anguilla bicolor bicolor (Mc Clelland, 1844) }\end{array}$ & $\begin{array}{l}A / I A \\
A / I P \\
A / I A \\
A / I A\end{array}$ \\
\hline $\begin{array}{l}\text { Ophichthidae } \\
\quad \text { Yirrkala tenuis (Günther, 1870) }\end{array}$ & $\mathrm{A} / \mathrm{IA}$ \\
\hline $\begin{array}{l}\text { Salmonidae } \\
\quad \text { Oncorhynchus mykiss (Walbaum, 1792) }\end{array}$ & I \\
\hline $\begin{array}{l}\text { Mugilidae } \\
\text { Valamugil cunnesius (Valenciennes, 1836) } \\
\text { Valamugil robustus (Günther, 1861) } \\
\text { Valamugil seheli (Forsskal, 1775) } \\
\text { Mugil cephalus (Linnaeus, 1758) } \\
\text { Agonostomus telfairii (Bennett, 1831) }\end{array}$ & $\begin{array}{l}\text { A/IP } \\
\text { A/IA } \\
\text { A/IP } \\
\text { A/C } \\
\text { A/MM }\end{array}$ \\
\hline $\begin{array}{l}\text { Poeciliidae } \\
\quad \text { Poecilia reticulata (Peters, 1860) } \\
\quad \text { Xiphophorus hellerii (Heckel, 1848) } \\
\quad \text { Xiphophorus maculatus (Günther, 1866) }\end{array}$ & $\begin{array}{l}\text { I } \\
\text { I }\end{array}$ \\
\hline $\begin{array}{l}\text { Syngnathidae } \\
\text { Microphis brachyurus millepunctatus (Kaup, 1856) }\end{array}$ & $\mathrm{A} / \mathrm{IA}$ \\
\hline $\begin{array}{l}\text { Chandidae } \\
\text { Ambassis gymnocephalus (Lacépède, 1802) }\end{array}$ & $A / I A$ \\
\hline $\begin{array}{l}\text { Kuhliidae } \\
\quad \text { Kuhlia rupestris (Lacépède, 1802) }\end{array}$ & $\mathrm{A} / \mathrm{IP}$ \\
\hline $\begin{array}{l}\text { Cichlidae } \\
\quad \text { Oreochromis niloticus (Linnaeus, 1758) }\end{array}$ & I \\
\hline $\begin{array}{l}\text { Eleotridae } \\
\quad \text { Eleotris fusca (Bloch and Schneider, 1801) } \\
\text { Eleotris mauritianus (Bennett, 1831) } \\
\text { Hypseleotris cyprinoides (Val. in Cuvier et Valenciennes, 1837) EXTINCT? }\end{array}$ & $\begin{array}{l}A / I P \\
A / I A \\
A / I P\end{array}$ \\
\hline $\begin{array}{l}\text { Belontiidae } \\
\quad \text { Trichogaster trichopterus (Pallas, 1770) }\end{array}$ & 1 \\
\hline $\begin{array}{l}\text { Gobiidae } \\
\quad \text { Awaous nigripinnis (Valenciennes, 1837) } \\
\text { Glossogobius giurus (Hamilton and Buchanan, 1822) } \\
\text { Sicyopterus lagocephalus (Pallas, 1770) } \\
\text { Cotylopus acutipinnis (Guichenot, 1863) }\end{array}$ & $\begin{array}{l}\text { A/EM } \\
\text { A/MM } \\
\text { A/IA } \\
\text { A/ER }\end{array}$ \\
\hline
\end{tabular}

(1) For autochtonous species (A) only. ER, Endemic of Réunion island; EM, Endemic of Mascarenes; MM, Endemic of Madagascar/Mascarenes area; IA, Indo-African species; IP, Indo-Pacific species; C, Cosmopolitan species. I, Introduced species. 


\section{Table II}

Decapod Crustacean species of Réunion and distribution area.

\section{Tableau II}

Espèces de crustacés décapodes de la Réunion et aire de distribution.

\begin{tabular}{ll}
\hline Species & Distribution area (1) \\
\hline Atyidae & \\
Atyoida serrata (Bate, 1888) & A/EM \\
Caridina typus (Milne-Edwards, 1837) & A/IP \\
Caridina nilotica (Roux, 1833) & $\mathrm{A} / \mathrm{IP}$ \\
Caridina serratirostris (De Man, 1892) & $\mathrm{A} / \mathrm{IP}$ \\
Palaemonidae & \\
Macrobrachium australe (Guérin and Meneville, 1838) & $\mathrm{A} / \mathrm{IP}$ \\
Macrobrachium leptidactylus (Hilgendorf, 1879) & $\mathrm{A} / \mathrm{A}$ \\
Macrobrachium lar (Fabricius, 1798) & $\mathrm{A} / \mathrm{IP}$ \\
Macrobrachium rosenbergii (Günther, 1866) & $\mathrm{I}$ \\
Macrobrachium hirtimanus (Olivier, 1811) EXTINCT? & $\mathrm{A} / \mathrm{EM}$ \\
Palaemon concinnus (Dana, 1852) & $\mathrm{A} / \mathrm{IP}$ \\
Grapsidae & \\
Varuna litterata (Fabricius, 1798) & $\mathrm{A} / \mathrm{IP}$ \\
\hline
\end{tabular}

(1) For autochtonous species (A) only. ER, Endemic of Réunion island; EM, Endemic of Mascarenes; IA, Indo-African species; IP, Indo-Pacific species. I, Introduced species.

As in most islands of the Indo-Pacific province, Réunion has no indigenous primary fish species; the rainbow trout was introduced, and so were the secondary species (Cichlidae and Poeciliidae). Only two vicarious fish species were found: Kuhlia rupestris and Agonostomus telfairii, while the diadromous catadromous fish species are all eels (Anguilla marmorata, Anguilla bicolor, Anguilla bengalensis and Anguilla mossambica). Due to the absence of primary fish species and of indigenous secondary fish species, the island's rivers are mainly colonised by diadromous amphidromous fish species, with two families (Gobiidae and Eleotridae) whose distribution depends mainly on two closely related factors, altitude and current speed. Lastly, sporadic fishes do not colonise the lower reaches. On Réunion, they belong to 4 families: Ophichthidae, Syngnathidae, Mugilidae and Chandidae.

Two species only can be found from the lower areas through to the upper reaches (Anguilla marmorata and Sicyopterus lagocephalus). The number of freshwater fish species found in a river decreases slowly as one moves upstream. The decline is dramatic after a waterfall.

Réunion has no indigenous primary crustacean species. The genus Macrobrachium is diadromous amphidromous.

Finally, one species is endemic to Réunion (Cotylopus acutipinnis) (WATSON, 1995) (Figure 1), 5 are endemic to the Mascarenes or to the Madagascar-Mascarenes region, 10 are Indo-African species, 13 are Indo-Pacific species, one is a cosmopolitan species and 7 are introduced species (Table I and Table II). 


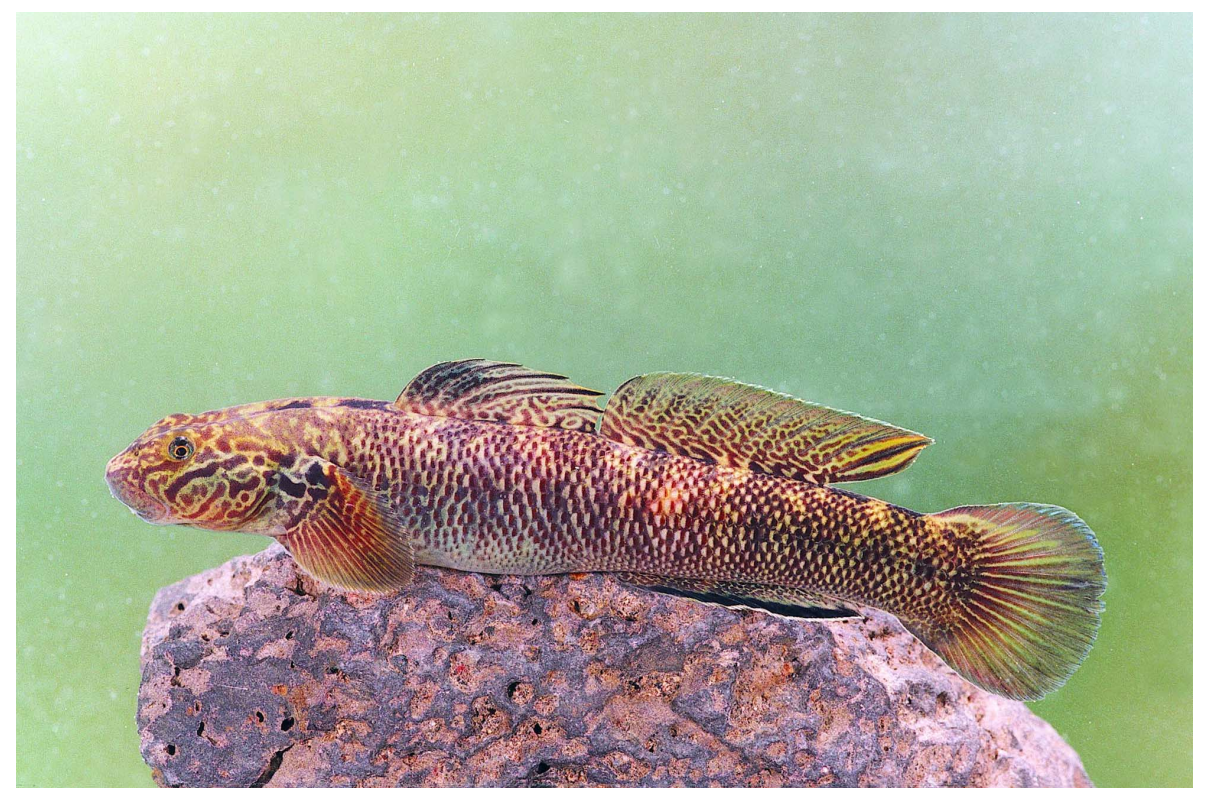

Figure 1

Cotylopus acutipinnis, an endemic species of Réunion Island (Picture E. Vigneux).

\section{Figure 1}

Cotylopus acutipinnis, une espèce endémique de la Réunion (Photo E. Vigneux).

\section{AUTOCHTONOUS SPECIES}

According to MARQUET et al. (1997), Indo-Pacific species prevail in Tahiti (French Polynesia) and in New Caledonia, where they make up $42.1 \%$ and $41.1 \%$ of all species, followed by species originating from the Pacific region, with $36.8 \%$ and $35 \%$ of the total. In Réunion, the proportion of Indo-Pacific species is slightly lower (35.2\%), but Indo-African species make up $27 \%$ of the total. In all three cases, Gobiidae are the prevailing family amongst fish species, with the highest number of species. RYAN (1991) noted that this family is very successful in colonising the Indo-Pacific islands. This is also the case in the Indian Ocean. Within the crustaceans, the prevailing family is the Palaemonidae. The proportion of species endemic to Réunion sensu stricto reaches $2.7 \%$, a figure lower to the one reported by MARQUET et al. (1997) for Tahiti (5\%) and KEITH et al. (2002) for all French Polynesia (31\%) and lower than the figure for New Caledonia (22\%) (MARQUET et al., 2001).

Macrobrachium lepidactylus (Crustacea, Décapoda) was reported on the island for the first time in 1999 (KEITH and VIGNEUX, 2000). The discovery of Macrobrachium lepidactylus on Réunion Island is significant, because it means that the known range of the species can be extended eastward. HOLTHUIS (1980) reported it from waterways in Kenya, Mozambique, South Africa, and Madagascar, but it had so far remained unknown from the lesser islands of the Indian Ocean, in particular from the Mascarenes. Adult specimens are found in waterfall basins where the water is constantly stirred and oxygenated; they are also found in river mouths (lower reaches of a river, between 0 and $200 \mathrm{~m}$ a.s.l., with a current flowing at $20-70 \mathrm{~cm} / \mathrm{s}$, with an average gradient under $10 \%$, and with pebbles and stones on the bottom). It appears to be active mainly at dusk and during the night.

Moreover, two species previously reported as present on Réunion were not found. 
The first species not found is Hypseleotris cyprinoides Valenciennes in Cuvier and Valenciennes, 1837. The species was described from two specimens captured in the $19^{\text {th }}$ century by Mr Leschenault in the estuary of a Réunion river - with no further details. It has never been recaptured since. This species is supposed to live from the Indo-Pacific region of the Mascarenes up to the Japanese archipelago.

The second species is a crustacean endemic to the Mascarenes, Macrobrachium hirtimanus (Olivier, 1811). It has been reported from the Marsouins River (ROUX, 1934; KIENER, 1981). KIENER (1981) included in his paper a black-and-white photo representing two adult males caught in 1980 in the Marsouins River. He also reports the species from the East and Mât Rivers. But this species was not found on these rivers since this date. Its habitat is supposed to be similar to that of $M$. lepidactylus. Macrobrachium hirtimanus is supposed to be present only in the Mascarenes area located between Réunion and Mauritius. This would make it an endemic to the area with high heritage-related value. It appears to be very rare nowadays (if not extinct) and it is highly threatened through poaching for food and loss of habitat (KEITH et al., 1999).

\section{INTRODUCED SPECIES}

Table III shows the results of species introductions on Réunion. The definition of an acclimatised species used here is the definition put forward by SHAFLAND and LEWIS (1984), augmented by KEITH and ALLARDI (1997).

Of the 7 introduced species captured, only 4 have become acclimatised. The rainbow trout (O. mykiss) lives in some basin heads and areas often cut off from the rest of the river by impassable obstacles (e.g. waterfalls); the tilapia (O. niloticus) is found in all lower areas, in rivers and coastal ponds, where it is the dominant species; the guppy ( $P$. reticulata) and the swordtail ( $X$. hellerii) are found in almost all rivers, in the lower and middle reaches. Only few specimens of Xiphophorus maculatus, Archocentrus nigrofasciatus, Trichogaster trichopterus and Macrobrachium rosenbergii were captured and it is at present difficult to assess their degree of acclimatisation.

So it appears that very few species have become acclimatised considering the high number of species introduced since the $18^{\text {th }}$ century (introduction attempts involved no less than 16 species - Table III). Their long history on Réunion is linked to that of the "Société impériale zoologique d'acclimatation » (Imperial Zoological Acclimatisation Society). Based in Paris, the "Société impériale zoologique d'acclimatation " was directed to the public benefit on February the $26^{\text {th }}, 1855$. Its objectives were to encourage acclimatisation and domestication of useful or ornamental animal species, and to improve and multiply newly introduced or newly domesticated breeds. It rewarded anyone who managed to acclimatise a new animal or plant species. The organisation was effectively divided into five branches: mammals, birds, aquiculture, sericiculture - apiculture, and plants. The third branch dedicated itself mainly to fish (KEITH, 1998).

The Society's influence reached the French provinces and overseas territories where a number of local acclimatisation societies were set up. These played an important part in the distribution of exotic animals and their dispersal throughout France. They were used as laboratories for putting to the test new ideas initiated in the National Society. Similarly, the fact that the members of the National Society were widely distributed meant that experiments could be conducted over a very wide area. This is how Mr Berg came to be delegated by the Imperial Society in Paris to establish an Acclimatisation Society in Réunion, following the terms of a local order issued on September the $18^{\text {th }}, 1962$ (BERG, 1863). Its members introduced several exotic species to the island. The first species were also imported by merchant ships or reconnaissance expeditions. 


\section{Table III}

Introduced species in Réunion Island.

\section{Tableau III}

Espèces introduites à la Réunion.

\begin{tabular}{|c|c|}
\hline Species & Date of introduction \\
\hline $\begin{array}{l}\text { ACCLIMATISED } \\
\text { Fishes } \\
\text { Salmonidae } \\
\text { Oncorhynchus mykiss }\end{array}$ & 1940 \\
\hline $\begin{array}{l}\text { Poeciliidae } \\
\text { Poecilia reticulata } \\
\text { Xiphophorus hellerii }\end{array}$ & $\begin{array}{l}>1908 \\
>1952\end{array}$ \\
\hline $\begin{array}{l}\text { Cichlidae } \\
\text { Oreochromis niloticus }\end{array}$ & 1957 \\
\hline $\begin{array}{l}\text { NON ACCLIMATISED } \\
\text { Fishes } \\
\text { Cyprinidae } \\
\text { Cyprinus carpio } \\
\text { Carassius auratus }\end{array}$ & $\begin{array}{c}1880 \\
18^{\text {th }} \text { century }\end{array}$ \\
\hline $\begin{array}{l}\text { Esocidae } \\
\text { Esox lucius }\end{array}$ & 1843 \\
\hline $\begin{array}{l}\text { Poeciliidae } \\
\text { Gambusia affinis }\end{array}$ & $>1930$ \\
\hline $\begin{array}{l}\text { Cichlidae } \\
\text { Oreochromis mossambicus } \\
\text { Oreochromis macrochir } \\
\text { Tilapia zillii }\end{array}$ & $\begin{array}{l}1957 \\
1957 \\
1956\end{array}$ \\
\hline $\begin{array}{l}\text { Osphronemidae } \\
\text { Osphronemus goramy }\end{array}$ & 1795 \\
\hline $\begin{array}{l}\text { INSUFFICIENTLY KNOWN } \\
\text { Fishes } \\
\text { Poeciliidae } \\
\text { Xiphophorus maculatus }\end{array}$ & 1980 \\
\hline $\begin{array}{l}\text { Belontiidae } \\
\text { Trichogaster trichopterus }\end{array}$ & $>1990$ \\
\hline $\begin{array}{l}\text { Cichlidae } \\
\text { Archocentrus nigrofasciatus }\end{array}$ & 1999 \\
\hline $\begin{array}{l}\text { Crustaceans } \\
\text { Palaemonidae } \\
\text { Macrobrachium rosenbergii }\end{array}$ & $>1980$ \\
\hline
\end{tabular}

Of all the species that ancient navigators tried to introduce on Réunion, the goldfish (Carassius auratus (Linnaeus, 1758)) was the first brought to the island by Mr Céré in the second half of the $18^{\text {th }}$ century. The species was introduced to Madagascar in 1861 by Laborde who donated 7 specimens to the Queen; they were released in Anosy pond and soon dispersed into the rivers (KEITH et al., 1999). Then came the gourami 
(Osphronemus goramy (Lacépède, 1801)) which was imported to Mauritius in 1761 from the Far East (China and Batavia) by two French navy officers, MM de Magny and Surville. This is where Commerson (in 1770) et Aubert Dupetit-Thouars found it. The former then created the genus Osphronemus. From Mauritius, this fish was taken to Réunion (VINSON, 1861) by inhabitants who sent specimens to friends and family. The first specimens were received by Mr Desmanières in 1795 (DABRY DE THIERSANT, 1870). But the species never became acclimatised (RUFZ DE LAVISON, 1861).

Finally came the carp (Cyprinus carpio (Linnaeus, 1758)). Coming back from Europe in 1830 or thereabout, $\mathrm{Mr} \mathrm{O}$. Lemarchand brought with him a number of carps who travelled in a sawn off barrel made into a bucket (VINSON, 1868). Bearing in mind that these carps travelled around the Cape of Good Hope and that the trip took over 3 months, the man who introduced them must have been very patient and dedicated. He landed on Réunion with about 30 intact, healthy, and vigorous carps; they were deposited in a fishtank on his estate in Saint Paul where he tried to farm them (KEITH et al., 1999).

\section{These species never became acclimatised.}

Between 1950 and 1956, Madagascar Forestry Authority introduced 4 tilapia species for farming. Production of Oreochromis mossambicus (Peters, 1852), in particular in paddy fields, reached such levels that the authorities on Réunion decided to introduce the species to the island. In February 1956, 80 young Tilapia zillii (Gervais, 1848) were thus imported from Madagascar - from the Centre Technique Forestier Tropical (CTFT), in Tananarive. The first specimens were released in various tanks in a forestry nursery, in La Providence (Saint-Denis). The others were brought to Hell-Bourg, in the Salazie cirque, and put in a salmon farming tank. The first reproduction took place on November the $13^{\text {th }}, 1957$, in Mare-Sisahayes. The forestry authority also initiated fry stocking operations in state-owned waters and distributed tilapias to private individuals who owned a tank suitable for fish farming. Between 1957 and 1972, 3450 O. macrochir (Boulanger, 1912), 11000 T. zillii, 1000 O. mossambicus, and 550 O. niloticus (Linné, 1758) were given to private individuals (ROBERT, 1976a, 1977).

In 1981, KIENER reported that $T$. zillii had become very rare and localised in Cilaos and Salazie ponds, that $O$. mossambicus was rare, and that the dominant form was a hybrid between $O$. niloticus and $O$. macrochir. This appears to be the only form currently present since the others were not found.

As early as April 1922, fertilised rainbow trout eggs (Oncorhyncus mykiss (Walbaum, 1792)) were sent by Professeur Léger from his fish farm in Vizilles, Isère (France) to Analamazaotra station in Madagascar. In 1924, a typhoon destroyed two years of work. Experimentation was then relocated to Manjakatompo station, in the Ankaratra mountain. In 1940, M. Benoît, who headed the forestry authority, imported the species from Madagascar to Réunion. The war disrupted experimentation and in 1946 the forestry authority decided to follow up on Mr Benoît's work. As early as 1950 Manjakatompo station sent fertilised eggs to Réunion.

In 1948-1949, surveys conducted by forestry agents proved that the trouts introduced in 1940 had adapted and reproduced. From 1950 to 1955, the eggs imported from Madagascar produced young trouts used for restocking selected torrent stretches. Over the period 1961-1972, out of c. 96500 fertilised eggs sent out from Madagascar, over 42000 were effectively incubated - and close to 25500 young hatched - while over 22600 were dispersed in the rivers and the rest kept in fish farming tanks (ROBERT, 1976b, 1978).

From 1972 onwards, political changes in Madagascar made it difficult to obtain eggs from Manjakatompo, and so eggs were imported from Norway; Denmark, South Africa, the 
United States and Australia. To date, the rainbow trout holds on in Réunion, in the upper reaches of several watercourses where it breeds without any human interference.

Several Poeciliidae species were introduced to Réunion in order to contain the proliferation of mosquito larvae and thus eliminate malaria. These were the mosquito fish (Gambusia affinis Baird and Girard, 1853) which had been introduced to Madagascar in 1929 , in the Tananarive area, from stock originating from the South of France, and the guppy (Poecilia reticulata Peters, 1859) which had first been imported to Mauritius in 1908 (PELLEGRIN, 1933). The mosquito fish has not been found in the course of this study, but the guppy is present in all the catchment basins we prospected. Other species were introduced to Réunion, either to contain the mosquitoes or for ornamental purposes, such as the xipho swordtail (Xiphophorus hellerii Heckel, 1848) - introduced in 1952 by professor $\mathrm{J}$. Arnoult to the highlands of the Majunga area, Madagascar, and now widespread on Réunion, sharing its habitats with the guppy - or the platy (Xiphophorus maculatus Günther, 1866) still rare and localised on Réunion.

As for the pike (Esox lucius Linnaeus, 1758), it was imported in February 1843 by Mr Lemarchand but it never became acclimatised.

Finally, some specimens of three more species were recently captured, but they do not appear to have become acclimatised: the shrimp Macrobrachium rosenbergii (Günther, 1866), probably escaped from breeding farms, Archocentrus nigrofasciatus (Günther, 1867) and Trichogaster trichopterus (Pallas, 1770) probably escaped from the pet trade. Both fish farming and the pet trade keep many more species, and there is always a real risk that these might be find their way into the natural environment.

\section{CONCLUSION}

Following the present study, freshwater fish and crustacean populations of Réunion are now well documented. $81 \%$ of the species are indigenous and $16.2 \%$ are endemic to Réunion, the Mascarenes or the Madagascar-Mascarenes region. So far, only $25 \%$ of all introduced species have become acclimatised. Of all indigenous species formerly reported, some have not been found again which suggests a sharp decline or even extinction. It is therefore essential to improve knowledge on aquatic ecosystems if one is to identify effective threats both to the habitats themselves and to the related biocenosis. Because of both the mountainous terrain and the hydrological regime of the island's watercourses, freshwater populations can establish themselves permanently only on very short river stretches. Because of this, fish and crustacean populations are very vulnerable in view of the increase in human activities on the island. Human behaviour is obviously responsible for whatever decline was reported and will determine the future of all natural populations. Any management on a sustainable basis will have to take into account the biological requirements of the species, show a proper respect for natural habitats, and rationalise the way living resources are used. The conservation of species endemic to Réunion and the Mascarenes, or even to the Madagascar-Mascarenes region, is largely the responsibility of the people of Réunion. This conservation entails the implementation of concerted action programmes involving all those using the island's waters or its environment, and exploiting its living resources, i.e. a sustainable management of all components of the ecosystems. This will be the second phase of the programme to be implemented by the Ministry of the Environment.

\section{ACKNOWLEDGEMENTS}

I would like to thank L. B. Holthuis and R. E. Watson for identifying a part of the samples, E. Vigneux, J.F. Ricou, Y. Zitte and P. Bosc (ARDA) and the DIREN for their warm welcome during the studies. 


\section{REFERENCES}

ARNOULT J., 1959. Poissons des eaux douces. Faune de Madagascar. Institut de Recherche de Tananarive, Tsimbazaza (ed.), $161 \mathrm{p}$.

BANARESCU P., 1990. Zoogeography of freshwater. General distribution and dispersal of freshwaters animals. Aula Verlag, Wiesbaden (ed.), $511 \mathrm{p}$.

BERG, 1863. Lettre adressée par M. le Dr Berg, délégué de la Société à l'île de la Réunion à $\mathrm{M}$. le président de la Société Impériale d'Acclimatation. Bulletin de la société impériale zoologique d'acclimatation, 10, 576.

BLEEKER P., POLLEN F.P.L., 1874. Poissons de Madagascar et de l'île de La Réunion. Leiden, $104 \mathrm{p}$.

BOSC P., DELACROIX P., FERRAND P., MABILLE A., 1997. Inventaire biologique des cours d'eau pérennes de l'île de la Réunion. ARDA/DIREN (Eds.), St Denis de la Réunion, $130 \mathrm{p}$.

COUTIĖRE H., 1901a. Les Palaemonidés des eaux douces de Madagascar. Annales de sciences naturelles, Zoologie, 8 (12), 280-340.

COUTIĖRE H., 1901b. Les Palaemonidae des eaux douces de Madagascar. In : Histoire physique, naturelle et politique de Madagascar. GRANDIDIER M.A. (ed.), Paris, 249-342.

CUVIER G., VALENCIENNES A., 1837. Histoire Naturelle des poissons, LEVRAULT (ed.), Paris, 22 vol.

DABRY DE THIERSANT P., 1870. Histoire naturelle du Gourami. Bulletin de la société impériale zoologique d'acclimatation, $2^{\text {ime }}$ série, 7, 671-688.

GUICHENOT M., 1862. Faune ichtyologique C10. In : Notes sur l'ile de La Réunion. MAILLARD M. (ed.), Paris, 1-32.

HOLTHUIS L.B., 1950. The decapoda of the Siboga expedition. The Palaemonidae collected by the Siboga and Snellius expeditions with remarks on other species. I. Subfamily Palaemonidae. Siboga Expeditie, Leiden, 39, 1-268.

HOLTHUIS L.B., 1952. On some Indo-Westpacific Palaemoninae (Crustacea decapoda Caridea). Zoologishe mededelingen, 31 (18), 201-211.

HOLTHUIS L.B., 1965. The Atyidae of Madagascar. Mémoires du Muséum National d'Histoire Naturelle, Zoologie, 33 (1), 1-48.

HOLTHUIS L.B., 1980. Shrimps and prawns of the world, an annnoted catalogue of species of interest to fisheries. FAO Fisheries Synopsis $N^{\circ} 125$ (1). 230 p.

KEITH P., 1998. Evolution des peuplements ichtyologiques de France et stratégies de conservation. Ph D Thesis, Université de Rennes I, $236 \mathrm{p}$.

KEITH P., ALLARDI J., 1997. The introduced freshwater fish of France, status, impacts and management. In : Stocking and introduction of fish. Fishing News Book, Blackwell Science, Oxford. (ed.), 153-156.

KEITH P., VIGNEUX E., 2000. First capture of Macrobrachium lepidactylus (Hilgendorf, 1879) (Crustacea: Palaemonidae) on Réunion Island, followed by a commentary on Macrobrachium hirtimanus (Olivier, 1811). Crustaceana, 73 (2), 215-222.

KEITH P., VIGNEUX E., BOSC P., 1999. Atlas des poissons et crustacés d'eau douce de la Réunion. Patrimoines naturels, 39, 1-136.

KEITH P., VIGNEUX E., MARQUET G., 2002. Atlas des poissons et crustacés d'eau douce de la Polynésie française. Patrimoines naturels, sous presse.

KIENER A., 1963a. Poissons, pêche et pisciculture à Madagascar. Centre Technique Forestier Tropical (ed.), Paris, étude $\mathrm{N}^{\circ} 24,221 \mathrm{p}$.

KIENER A., 1963b. Aperçu de quelques aspects piscicoles de la Réunion (eaux intérieures de l'île). Centre Technique Forestier Tropical (ed.), Paris, 1-15.

KIENER A., 1981. Etude des problèmes piscicoles des eaux intérieures de la Réunion. Cemagref, Aix en Provence (ed.), étude $\mathrm{N}^{\circ} 25,140 \mathrm{p}$.

MAILLARD M., 1862. Notes sur l'île de La Réunion. MAILLARD M. (ed.), Paris, 110 p.

MARQUET G., SERET B., LECOMTE-FINIGER R., 1997. Inventaires comparés des poissons des eaux intérieures de trois îles océaniques tropicales de l'Indo-Pacifique (La Réunion, La Nouvelle-Calédonie et Tahiti). Cybium, 21 (1) suppl., 27-34. 
MARQUET G., KEITH P., VIGNEUX E., 2001. Inventaire des poissons et des crustacés d'eau douce de la Province nord de la Nouvelle-Calédonie, MNHN/Province nord, $82 \mathrm{p}$.

MYERS G.S., 1938. Freshwater fishes and West Indian zoogeography. Annals Report Smithsonian Institute, 1937, 339-364.

PELLEGRIN J., 1933. Les poissons des eaux douces de Madagascar et des îles voisines. Mémoire de l'Académie Malgache, 14, 1-222.

ROBERT R., 1976a. La pisciculture du Tilapia à La Réunion. Revue Forestière Française, 28, 378-386.

ROBERT R., 1976b. L'introduction de la truite arc-en-ciel à la Réunion. Revue forestière française, 5, 386-387.

ROBERT R., 1977. Pêche et Aquaculture à la Réunion. Publications du Centre Universitaire de la Réunion (ed.), St Denis, $93 \mathrm{p}$.

ROBERT R., 1978. La salmoniculture à l'île de La Réunion. Revue Bois et Forêts des Tropiques, 77, 65-70.

ROUX J., 1934. Macroures d'eau douce de Madagascar et des îles voisines (Palaemonidés et Atyidés). Faune des Colonies Françaises, 5, 529-547.

RUFZ DE LAVISON E., 1861. Notes sur quelques tentatives d'acclimatation du gourami (O. olfax) dans divers pays. Bulletin de la société impériale zoologique d'acclimatation, 8, 392-403.

RYAN P.A., 1991. The success of the Gobiidae in tropical Pacific insular streams. New Zealand journal of zoology, 18, 25-30.

SAUVAGE H.E., 1891. Histoire naturelle des poissons de Madagascar. In : Histoire physique, naturelle et politique de Madagascar. GRANDIDIER M.A. (ed.), Paris, 16.

SHAFLAND P.L., LEWIS W.M., 1984. Terminology associated with introduced organisms. Fisheries, 9, 17-18.

VINSON A., 1861. De l'acclimatation du gourami à l'île de la Réunion et des moyens d'acclimater ce poisson en Algérie et dans le midi de la France. Bulletin de la société impériale zoologique d'acclimatation, 8, 509-514 and 541-546.

VINSON A., 1868. De l'acclimatation à l'île de La Réunion. Bulletin de la société impériale zoologique d'acclimatation, $2^{\text {eme }}$ série, 5, 579-590 and 625-638.

WATSON R.E., 1995. Review of the freshwater goby genus Cotylopus (Pisces, Teleostei, Gobiidae, Sicydiinae). Ichthyological Exploration of Freshwaters, 6 (1), 61-70. 
